Jurnal Pengurusan 55(2019) $159-167$

https://doi.org/10.17576/pengurusan-2019-55-13

\title{
Hubungan Pengaruh Gaya Kepemimpinan Transformasional terhadap Perlaksanaan Program Pelan Penggantian Pembangunan Kerjaya dalam Perkhidmatan Awam Malaysia
}

\author{
(The Relationship between Transfomational Leadership Styles towards Implementing Succession Planning \\ Program Career Development in Malaysian Public Sector) \\ Rohana Ahmad \\ (Pusat Pengajian Pembangunan Sosial Dan Ekonomi, Universiti Malaysia Terengganu) \\ Ahmad Martadha Mohamed \\ (Kolej Undang-Undang, Kerajaan dan Pengajian Antarabangsa, Universiti Utara Malaysia)
}

ABSTRAK

Program pelan penggantian yang sistematik dan pembangunan kerjaya yang kukuh merupakan perkara yang penting kepada penjawat awam. Kajian sebelom ini membuktikan bahawa terdapat hubungan signifikan antara pembangunan kerjaya dengan sokongan pihak pengurusan tertinggi. Oleh itu, program pembangunan kerjaya, organisasi bukan sahaja bergantung kepada pelan penggantian yang sistematik, tetapi perkara utama ialah komitmen jitu daripada pihak pengurusan tertinggi organisasi. Sehubungan itu, kajian ini ingin melihat hubungan antara ciri kepemimpinan transformasional terhadap perlaksanaan pelan penggantian di sektor awam Malaysia. Oleh demikian, kajian ini melihat kepada dimensi pengaruh kepemimpinan Bass dan Avolio (2004) iaitu pengaruh ideal, motivasi berinspirasi, pengaruh individu dan juga ransangan intelek. Selain itu, pembangunan kerjaya digunakan sebagai dimensi untuk mengukur pelan penggantian. Kaedah kuantitatif digunakan dalam kajian ini. Sebanyak 576 soal selidik diedarkan kepada pegawai kerajaan yang berjawatan antara gred 48 hingga gred 52 dan hanya 425 orang responden telah memberikan maklum balas. Hasil dapatan kajian daripada analisis regresi pelbagai menunjukkan terdapatnya hubungan yang signifikan antara pengaruh individu dengan pelan penggantian. Oleh itu, organisasi dalam sektor awam perlu memberi perhatian kepada gaya kepemimpinan pengurusan tertinggi supaya pelan penggantian kepemimpinan dapat dilaksankan dengan jayanya.

Kata kunci: Kepemimpinan transformasional; pelan penggantian; pembangunan kerjaya; sektor awam Malaysia

ABSTRACT

A systematic succession planning program, couple with solid career development is important to public employees. Previous studies reveal that there is a relationship between career development and top management support. Thus, to groom future leaders, it is of utmost important for organization not to rely on the systematic succession planning programs: but also to have full commitment from the top management. Therefore, this study intends to explore the relationship between leadership characteristic styles and succession planning program implementation in the public sector in Malaysia. Therefore, this study looks at the dimensions of leadership influence introduced by Bass and Avolio (2004), the ideal influence, inspirational motivation, individual influences as well as intellectual stimulation. Additionally, dimension that measure succession planning which is career development was also used. A quantitative method was evocated in this study. Quantitative research design was employed by distributing survey questionnaires to 576 Malaysian Public Sector government servants from Grade 48 to 64 and 425 questionnaires we returned. Based on multiple regression analysis, the finding demonstrate that individualised influence significantly related to succession planning program. Therefore, public sector needs to pay attention to leadership styles of top management so that succession-planning program can be implemented successfully.

Keywords: Career development; transformational leadership styles; succession planning; public sector Malaysia

\section{PENGENALAN}

Kepemimpinan memain peranan yang penting dalam organisasi terutama berhubung dengan pembangunan kerjaya. Kejayaan organisasi adalah bergantung kepada kepemimpinan yang berkesan (Leanard 2018; Oh, Cho \& Lim 2018). Kebanyakan ahli teori keorganisasian percaya bahawa kepemimpinan merupakan faktor utama dalam memastikan keberkesanan sesebuah organisasi (Papa, Daniel \& Spiker 1997; Ali, Ong \& Elsadiq 2013). Pendapat ini telah disokong dengan satu kajian yang dilakukan pada zaman pentadbiran Presiden Clinton di Amerika Syarikat yang bertujuan untuk mengkaji cara membaiki kecekapan dan keberkesanan sektor awam. Dapatan kajian menunjukkan bahawa organisasi yang mempunyai ketua yang berbakat, beriltizam dan 
berkebolehan, berkeupayaan memainkan peranan utama secara konsisten dalam menyumbang ke arah kecekapan dan kepuasan orang bawahan (Hennessey 1998). Disamping itu, seseorang pemimpin juga memerlukan kekuatan mental untuk mengubah amalan organisasinya sekiranya berlaku sebarang perubahan dan pengurusan. Seorang pemimpin seharusnya juga bertindak sebagai pemain utama yang boleh mengemudi organisasi dalam mencapai objektif organisasi (Daniel et al. 1997; Asrarul-Haq \& Kuchinke 2016; Semarco \& Cho 2017). Justeru itu, pemimpin berkeupayaan bertindak sebagai peranan utama dalam memastikan amalan terbaik dipraktiskan di semua peringkat organisasi. Mesu, Sender dan Riemsdijk (2015), Al-Ansi, Rahardjo dan Prasetya (2015), Ismail, Ishak dan Yusuf (2016) dan Setyaningrum, Setiawan dan Surachman (2017) menjelaskan bahawa terdapat hubungan yang signifikan antara pengurusan sumber manusia dan prestasi organisasi. Dapatan ini juga selaras dengan pandangan Voon, Ngui dan Ayob (2015) bahawa modal insan yang berpotensi dapat memberikan nilai tambah kepada organisasi.

Keberkesanan pengurusan sumber manusia akan menjadi lebih bermakna apabila kepemimpinan organisasi dapat menerima orang bawahan sebagai kesatuan dalam organisasi dan sentiasa memberi peluang ke arah memajukan pekerja (Nabi et al. 2017; Breaugh, Ritz \& Atles 2017). Oleh demikian sejajar dengan usaha untuk memantapkan perancangan dan penyusunan sumber manusia terutama dalam kemajuan kerjaya, pelan penggantian dilihat sebagai proses yang sangat berkesan serta juga signifikan. Sehubungan itu, setiap organisasi awam terutamanya pengurusan tertinggi perlu mempunyai perancangan yang berkesan untuk memberi peluang orang bawahan membina kerjaya mereka di sektor awam dengan menyediakan pelapis bagi persediaan kekosogan pemimpin masa hadapan. Hasil kajian lepas menunjukan bahawa pelan penggantian berupaya mengekang pengaliran keluar pekerja dari organisasi dan juga kestabilan (Church et al. 2015; Gulzar \& Durrani 2014). Sehubungan itu, kepimpinan dilihat sebagai pemangkin kepada keberkesanan organisasi (Sosik \& Jung 2010; Rasool 2015; Geh 2014). Walau bagaimanapun pemimpin perlu bergerak seiring dengan pengikut untuk mencapai objektif organisasi. Unsur kepemimpinan menjadi faktor terpenting dalam menentukan kestabilan dan keharmominan persekitaran organisasi (Al-Ansi et al. 2015; Ismail et al. 2016). Yang nyata, pemimpin organisasi mampu membentuk model peranan yang menjadi kewajaran untuk mengetahui seni tingkah laku untuk bertindak dengan tepat, di tempat yang betul dan pada waktu yang tepat.

Oleh demikian, kajian ini bertujuan untuk mengkaji terdapat hubungan signifikan antara pembolehubah terikat yang berdasarkan kepada pengaruh ideal, pengaruh motivasi berinspirasi, ransangan intelek dan pengaruh individu dan pembangunan kerjaya bagi pembolehubah bebas melalui persepsi penjawat awam dalam organisasi kerajaan.

\section{HUBUNG KAIT KEPEMIMPINAN \\ TRANSFORMASIONAL DENGAN PELAN PENGGANTIAN}

Kajian ini menyumbang kepada kesusasteraan perancangan penggantian dengan melakukan pemeriksaan sistematik kefahaman dan persepsi bawahan ke arah kepemimpinan yang mempengaruhi jalur kerjaya mereka. Untuk tujuan kajian ini, dianggap bahawa ciri kepemimpinan mempunyai pengaruh yang signifikan terhadap pelaksanaan dasardasar untuk mempelopori pemimpin masa depan dalam sektor awam di Malaysia. Penyelidikan ini memberi tumpuan kepada pembangunan pemahaman yang lebih holistik terhadap empat jenis faktor kepimpinan yang mempengaruhi dandanan pemimpin masa depan dalam sektor awam Malaysia.

Kepimpinan Transformasional berasal dari kepercayaan bahawa para pemimpin berkarisma seperti yang diandaikan oleh para pengikutnya bahawa pemimpin akan selalu mempertahankan pengikut kerana pemimpin memiliki jiwa yang besar (Abouraria \& Othman 2017; Krishnanathan \& Mangaleswaran 2018). Contohnya, Bennis dan Nanus (1985) serta Zhao et al. (2016) berpendapat bahawa pemimpin transformasional adalah orang yang memiliki keupayaan untuk menyentuh hati bawahan mereka. Menurut Bass dan Avolio (1999), Bass dan Riggio (2006), Wu (2017) serta Xu et al. (2018), pemimpin transformasional adalah pemimpin yang sentiasa memberi galakan, berkebolehan dalam penyampaian serta menetapkan standard tingkah laku yang boleh dicontohi oleh orang bawahan. Burn (1978) pengasas konsep kepemimpinan transformasional, telah menetapkan kepemimpinan transformasional sebagai "hubungan, rangsangan bersama yang mengubah pengikut menjadi pemimpin dan dapat mengubah pemimpin menjadi agen moral." Kajian terdahulu telah membuktikan bahawa kepimpinan transformasional memberi sumbangan positif kepada keberkesanan dan kecekapan organisasi (Guay 2013). Namun begitu, kini kebanyakan pemimpin dalam organisasi awam telah cuba menggabungkan kepimpinan transformasional dalam gaya pengurusan mereka kerana gaya kepemimpinan memberi inspirasi kepada pengikutnya (Gennaro 2018).

Menurut Bass (1985), para pemimpin transformasional menanamkan inspirasi kepada pengikutnya untuk meletakkan kepentingan organisasi melebihi kepentingan diri. Oleh demikian pemimpin jenis ini mempunyai wawasan mendalam dan memberi penghargaan setiap sumbangan anggota. Pemimpin transformasional lebih menumpukan kaedah motivasi bagi memberangsang pekerja dan menggalakkan pekerja berfikir secara kritikal untuk menyelesaikan masalah dan menggalakkan keterlibatan pekerja dalam kegiatan organisasi. Di samping itu juga memberi kepercayaan sepenuhnya kepada pekerja untuk mewujudkan kesetiaan kepada pemimpin dan organisasi. Selain itu, bagi memastikan wujudnya hubungan yang baik antara pemimpin dan orang bawahan, organisasi perlu mewujudkan wawasan yang 
difahami di semua peringkat (Lythreatis, Sayed \& Wang 2017; Tahir et al. 2017). Mempraktiskan komunikasi dua hala dan memperbanyakkan peluang-peluang kenaikan pangkat serta latihan berterusan agar pekerja dapat mempertingkatkan kemahiran mereka dan memberi ruang untuk perkembangan kerjaya (Mcknight 2013; Ho 2011). Justeru itu, kajian ini dikaji dengan bersandarkan kepada Teori Kepemimpinan Bass dan Avolio (2004) yang berlandaskan komponen kepemimpinan iaitu pengaruh ideal, motivasi berinspirasi, rangsangan intelektual dan pengaruh individu. Rangka konsep ini adalah seperti yang ditunjuk pada Rajah 1.

Pengaruh Ideal (Idealised Influence) Menurut Abdulla, Ramdane dan Kamel (2011) Chong (2014) pengaruh ideal merujuk kepada pemimpin yang berkeupayaan menonjolkan diri sebagai pemimpin yang boleh dicontohi dan dengan akhlak yang mulia. Pandangan ini juga selari dengan Haider dan Riaz (2010) yang menyatakan bahawa pemimpin ini menjadi "role model" dan berupaya untuk mempengaruhi pengikutnya. Justeru itu, cara kepemimpinan dilihat mempunyai perhubungan dengan persepsi orang bawahan terhadap pemimpin mereka. Malahan orang bawahan melihat sejauh mana keupayaan pemimpin dapat merealisasi keperluan pekerja di samping memberi tunjuk ajar dan merangsang ke arah kemajuan kerjaya.

Motivasi Inspirasi (Inspirational Motivation) Motivasi Inspirasi merujuk kepada pemimpin yang berkemampuan dalam memberangsangkan pekerjanya untuk mencapai objektif jabatan atau organisasi. Berkarismatik, berkeyakinan dan mempunyai wawasan yang jelas untuk memastikan matlamat organisasi akan dapat dicapai. Malahan ciri kepemimpinan ini bukan saja merangsang namun mencabar pekerja dengan standard yang tinggi, bercakap dengan penuh berkobar dan optimistik serta mendorong pekerja melakukan terbaik terhadap perkara yang dilakukan (Russell 2013; Cerni, Curtis \& Colmar 2014). Pemimpin ini bukan hanaya memotivasikan pekerja tetapi juga bersifat kritikal yang membolehkan orang bawahan membuat keputusan, mengkaji serta melihat keadaan mengikut situasi semasa. Menurut Ubben, Hudges dan Norris (2004) pemimpin yang mempunyai gaya motivasi memberi kebebasan kepada individu di samping menggalakkan melakukan pembaharuan dalam membuat keputusan sekiranya berhadapan masalah.

Pengaruh Individu (Individualized Influence) Kepemimpinan yang berdasarkan kepada gaya pengaruh individu adalah seorang pemimpin mementingkan emosi pekerja bawahan dengan memberi bimbingan kaunseling serta memberi dorongan untuk kemajuan kerjaya pekerjanya. Setiap pekerja diberi layanan secara individu berdasarkan kebolehan masing-masing dan pengetahuan yang ada pada pekerja berkenaan (Bass \& Avolio 2004) bagi memberi peluang kepada pekerja untuk berusaha dan mendapat peluang yang lebih baik untuk kenaikan pangkat (Ismail, Awis \& Mohd Amin 2011). Pemimpin yang mempunyai gaya ini mempamerkan sikap yang bagus dengan menjadi pendengar yang baik, berkarisma, seringkali mempertimbangkan kehendak subordinat di samping menasihati dan juga menjadi ketua yang boleh di percayai. Selain sokongan terhadap tindakan yang dibuat oleh pekerja, pemimpin juga memberi kebebasan kepada subordinatnya dalam membuat keputusan (Zhu, Avolio \& Walumbawa 2009).

Rangsangan Intelektual(Intelectual Stimulation) Dimensi kepemimpinan yang seterusnya ialah rangsangan intelektual iaitu pemimpin menggunakan kebijaksanaannya dalam menyelesaikan masalah. Dalam situasi tertentu pekerja masalah diberi kebebasan oleh pemimpin untuk menggunakan daya kreativiti dan juga inovasi masingmasing untuk menyelesaikan masalah yang dihadapi (Bass \& Avolio 2004). Pendekatan ini membolehkan pekerja menggunakan rangsangan intelektual mereka untuk berfikir secara kritis sekiranya menghadapi masalah dan dapat menyelesaikannya tanpa perlu mengharapkan bantuan pada yang lain. Abdullah dan Ainon (2007) menyatakan bahawa dengan cara ini pemimpin melatih subordinat untuk mempunyai keyakinan diri dalam menghadapi cabaran. Pemimpin dengan gaya rangsangan intelektual ini membuatkan organisasi sentiasa berada dalam keadaan yang kompeten (Hall et al. 2010).

Penbangunan Kejaya Pembangunan kerjaya merupakan salah satu dimensi dalam pelan penggantian yang merupakan elemen yang penting bagi seseorang pekerja. Pelan penggantian menurut Rothwell (2010) merupakan satu 'pengagihan sistematik' oleh sesebuah organisasi bertujuan memastikan terdapat kesinambungan kepemimpinan dalam jawatan peringkat utama, pembangunan kerjaya dan juga rangsangan kepada subrordinat. Pelan penggantian ini juga merupakan satu proses yang boleh membantu pekerja untuk kenaikan pangkat (career success) dan kestabilan pekerja organisasi (Falkiner et al. 2017; Earls \& Hall 2018). Malahan ianya merupakan satu usaha oleh organisasi untuk memastikan prestasi organisasi cemerlang dengan adanya kepuasan kepada pekerja dengan kekerapan melaksanakan pelan penggantian. Marshall (2005), menyatakan bahawa pelan penggantian harus dilihat sebagai proses pembangunan kerjaya yang bermula dengan pengambilan individu sepanjang perkhidmatan. Pendapat ini dipersetujui oleh Zepeda, Bengtson dan Parylo (2011) dan Barton (2019) dengan merujuk pelan penggantian adalah proses yang sistematik menyediakan individu untuk mengisi kekosongan organisasi pada masa hadapan. Selain itu, Melo (2011) melihat pelan penggantian sebagai proses kerja yang sistematik dan kritikal dalam mengenal pasti jawatan pengurusan utama dalam organisasi. Pelan penggantian juga merupakan proses mengenalpasti pekerja yang berpotensi serta berkemahiran tinggi, kecekapan, berpengetahuan dan berpengalaman dan pada masa yang tepat (Rothwell 2010).

Menurut Kirk et al. (2000) dan Chauhtai (2018) pembangunan kerjaya boleh digambarkan sebagai 
proses untuk mencapai matlamat pekerja dan organisasi, termasuk menyediakan maklumat kerjaya kepada pekerja, membantu pekerja mengenal pasti peluang kemajuan, menggalakkan kepuasan kerja dan meningkatkan produktiviti pekerja. Manakala Bowers (2008) dan Maurer, Hartnell dan Lippstreau (2017) menyatakan bahawa pembangunan kerjaya adalah satu strategi penting yang memudahkan promosi dalaman di samping merancang dan melaksanakan matlamat kerjaya. Kajian yang dijalankan oleh Adewale, Abolaji dan Kolade (2011) terhadap Pusat Pengajian Tinggi Swasta Nigeria menunjukkan bahawa terdapat hubungan yang signifikan pengaliran keluar pekerja dengan organisasi tersebut berhubung dengan pembangunan kerjaya. Pembangunan kerjaya juga boleh diertikan sebagai perancangan kerjaya (Mehrabani \& Mohamed 2011). Sementara itu, Weare (2015) juga menyatakan bahawa pelan penggantian juga perlu dilaksanakan di perpustakaan. Sehubungan itu, faktor yang membawa kepada pembangunan kerjaya ialah perancangan kerjaya yang perlu diambil berat oleh organisasi dan juga pemimpin (Rothwell 2010; Megheirkouni 2018). Ibarra (2005) mengenal pasti bahawa kepemimpinan di organisasi boleh membuat pilihan tiga (3) pendekatan untuk pelan penggantian iaitu melaksanakan pelan penggantian yang mudah, merancang pembangunan pelan penggantian serta mewujudkan perancangan bakat.

Di Malaysia terdapat kajian yang dijalankan berkaitan pelan penggantian seperti Julia (2009) hubungan organisasi dan kerjaya dan Fatimah (2012) berkaitan dengan keberkesanan pelan penggantian. Namun begitu, tidak terdapat kajian yang dijalankan berhubung pengaru gaya kepemimpinan terhadap perlaksanaan pelan penggantian. Oleh demikian, kajian ini diadakan bertujuan melihat sejauh mana gaya kepemimpinan transformasional di sektor awam mempengaruhi perlaksanaan pelan penggantian.

Oleh demikian, kajian ini meneliti hubungan keempat-empat dimensi pembolehubah bersandar dengan pembolehubah bebas dalam kontek gaya kepemimpinan dan pembangunan kerjaya. Justeru itu hipotesis yang dicadangkan ialah:

$\mathrm{H}_{\text {la }}$ Terdapat hubungan signifikan antara pengaruh ideal terhadap pembangunan kerjaya.

$\mathrm{H}_{1 \mathrm{~b}}$ Terdapat hubungan signifikan antara pengaruh motivasi berinspirasi terhadap pembangunan kerjaya.

$\mathrm{H}_{1 \mathrm{c}}$ Terdapat hubungan signifikan antara pengaruh individu terhadap pembangunan kerjaya.

$\mathrm{H}_{1 \mathrm{~d}}$ Terdapat hubungan signifikan antara pengaruh ransangan intelek pembangunan kerjaya.

\section{KERANGKA KAJIAN}

Kerangka kajian ini dihasilkan berlandaskan kepada teori kepemimpinan Bass dan Avolio (2004) serta pelan penggantian Rothwell (2005) di samping hasil dapatan kajian empirikal yang telah dijalankan oleh pengkaji terdahulu. Sehubungan itu, kerangka teoretikal melihat hubungan antara gaya kepemimpinan pengaruh ideal, pengaruh motivasi berinspirasi, pengaruh individu dan rangsangan intelek terhadap pembangunan kerjaya seperti mana dalam Rajah 1. Pengujian hipotesis akan dilakukan pada senua dimensi ciri kepemimpinan bagi melihat pengaruh kepemimpinan yang paling dominan terhadap

Pembolehubah Bebas Pembolehubah Bersandar Kepemimpinan Pelan Penggantian

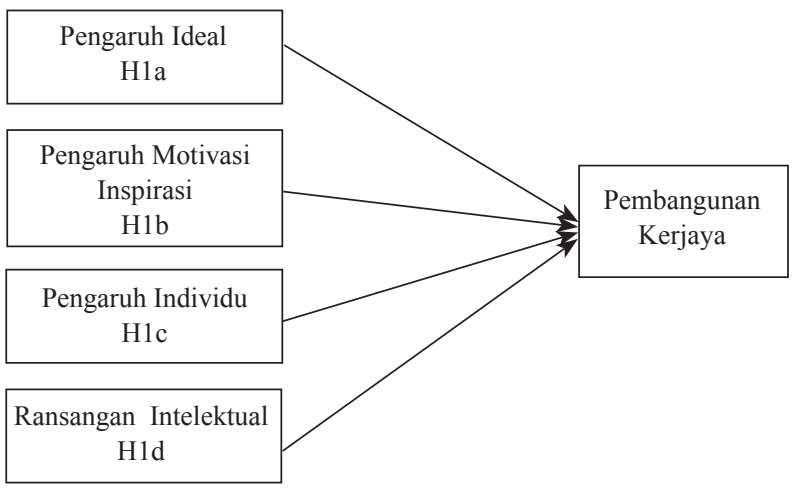

RAJAH 1. Kerangka konsep kajian pengaruh kepimpinan transformasional berdasarkan konsep Bass dan Avolio (2004)

terhadap program Pelan Penggantian (Rothwell 2005)

perlaksanaan pembangunan kerjaya.

\section{METODOLOGI KAJIAN}

Kajian ini dijalankan terhadap pekerja di sektor awam di Semenanjung Malaysia. Penjawat awam di 21 organisasi awam yang terdiri dari Gred 48 sehingga gred 52 telah dipilih sebagai responden dalam kajian ini. Pemilihan kumpulan ini adalah kerana keterlibatan mereka secara langsung dalam proses kemajuan kerjaya. Sehubungan itu, 576 responden telah dipilih dan diberikan borang soal selidik. Walau bagaimanapun seramai 425 responden telah mengembalikan semula. Sebanyak 394 borang terpilih untuk dianalisa. Peratus responden bagi kajian ini ialah $68.4 \%$. Kajian ini mengandungi dua variabel iaitu pemboleh ubah bebas ialah gaya kepemimpinan transformasional dan pelan penggantian pembolehubah bersandar. Soal selidik menggunakan Multifactor Leadership Questionnaire (MLQ) dengan Five-point Likerst Scale digunakan bagi pembolehubah bebas. MLQ ini telah dipelopori oleh Bass dan Avolio (2004) bagi mengukur kepemimpinan tansformatioanal. MLQ ini mempunyai 20 item: pengaruh ideal mempunyai 8 item, motivisai berinspirasi mempunyai 4 item, 4 item untuk pengaruh individu dan rangsangan intelektual mempunyai 4 item. Bagi mengekalkan kesahihan, kajian rintis telah dijalankan. Nilai alfa Cronbach adalah dari. 714 hingga .890 adalah boleh diterima (Hair et al. 1998). Manakala instrumen pelan penggantian pula menggunakan instrumen yang diperkenalkan Rothwell (2005) iaitu 
Succession Planning and Management (SPM). Sebanyak 10 item digunakan untuk mengukur pembangunan kerjaya dengan kaedah Five-point Likerst Scale. Hasil kajian rintis, nilai alfa Cronbach antara 0.699 hingga 0.904 adalah boleh diterima.

\section{DAPATAN KAJIAN}

HUBUNGAN GAYA KEPEMIMPINAN TRANSFORMASIONAL DENGAN PEMBANGUNAN KERJAYA

Kajian ini menunjukkan kepemimpinan transformasional melibatkan empat ciri kepemimpinan yang paling berkesan iaitu pengaruh ideal, pengaruh motivasi berinspirasi, pengaruh individu dan juga pengaruh rangsangan intelek. Sehubungan itu pembentukan hipotesis dalam kajian ini adalah bagi meramalkan hubungan antara ciri kepemimpinan dengan pelan pengantian. Data kajian ini menggunakan kaedah analisis regrasi pelbagai melalui perisian SPSS statistik 24. Analisis regrasi pelbagai digunakan untuk melihat hubungan yang signifikan antara gaya kepemimpinan dengan pembangunan kerjaya.

Jadual 1 dan Jadual 2 menunjukkan bahawa korelasi kesemua pembolehubah bebas (IV) dengan pembolehubah bersandar (DV) adalah sederhana $\left(\mathrm{R}=.375^{\mathrm{b}}\right)$. Adalah didapati bahawa kesemua pembolehubah bebas dapat

JADUAL 1. Ringkasan model

\begin{tabular}{cccccccccc}
\hline Model & $\mathrm{R}$ & $\mathrm{R}^{2}$ & Adjusted R $^{2}$ & Std Error the Etimate & $\mathrm{R}$ Square Change & $\mathrm{F}$ change & $\mathrm{df}^{1}$ & $\mathrm{Df}^{2}$ & Sig F Change \\
\hline 1 & $.111^{\mathrm{a}}$ & .012 & .002 & .44387 & .012 & 1.215 & 4 & 389 & .304 \\
2 & $.375^{\mathrm{b}}$ & .141 & .123 & .41620 & .128 & 14.360 & 4 & 385 & .000 \\
\hline
\end{tabular}

a. Predictors: Pengaruh ideal, pengaruh motivasi inspirasi, pengaruh individu, pengaruh rangsangan intelektual

b. Dependent Variable: Pembangunan kerjaya

JADUAL 2. Kesignifikan pembolehubah bebas

\begin{tabular}{clccccc}
\hline Model & & Sum of Square & $\mathrm{df}$ & Mean Square & $\mathrm{F}$ & Sig \\
\hline \multirow{2}{*}{1} & Regression & .957 & 4 & .239 & 1.215 & $.304^{\mathrm{b}}$ \\
& Resedual & 76.641 & 393 & .197 & & \\
\multirow{2}{*}{2} & Total & 77.598 & 394 & & & $.000^{\mathrm{c}}$ \\
& Regression & 10.907 & 8 & 1.368 & 7.871 & \\
& Residual & 66.691 & 385 & .173 & & \\
& Total & 77.598 & 394 & & & \\
\hline
\end{tabular}

menerangkan dari $12.3 \%$ daripada varians pembangunan kerjaya (DV). Regresi ini adalah signifikan dari $\mathrm{F}(4,385)$ $=14.360, \mathrm{p}<.05)$.

Ujian regresi pelbagai telah dijalankan bagi melihat terdapatnya hubungan antara gaya kepemimpinan yang terdiri dari pengaruh ideal, pengaruh motivasi berinsiprasi, pengaruh individu dan rangsangan intelek dengan pembangunan kerjaya. Keputusan analisa regresi pelbagai di antara gaya kepemimpinan transformasional dan pelan penggantian ditunjukkan pada Jadual 3. Hasil dapatan membuktikan bahawa tiga pembolehubah bebas (IV) iaitu pengaruh ideal, motivasi berinspirasi dan rangsangan intelek adalah berkait secara positif dan tidak

JADUAL 3. Analisa regrasi berganda di antara kepemimpinan transformasional dengan pembangunan kerjaya

\begin{tabular}{|c|c|c|c|c|c|c|}
\hline \multirow[t]{2}{*}{$\begin{array}{c}\text { Model } \\
1\end{array}$} & & $\begin{array}{l}\text { Unstanderdized } \\
\text { Coefficients }\end{array}$ & Std Coeff & $\mathrm{t}$ & $\operatorname{sig}$ & $\begin{array}{l}95 \% \text { Confidential } \\
\text { Interval (CI) }\end{array}$ \\
\hline & & Beta std Error & Beta & & & Lower Upper Bound \\
\hline \multirow[t]{5}{*}{2} & Konstan & 1.717 & & & & \\
\hline & P. Ideal & .085 .065 & .081 & 1.304 & .193 & .043 .213 \\
\hline & Motivasi & .081 .058 & .093 & 1.409 & .160 & .032 .198 \\
\hline & P. Individu & .138 .051 & .165 & 2.718 & .007 & .038 .237 \\
\hline & Rangsangan Intelek & .104 .064 & .105 & 1.633 & .103 & .021 .230 \\
\hline
\end{tabular}


signifikan dengan pembolehubah bersandar (DV) kecuali pembolebubah pengaruh individu yang berhubung secara positif dan signifikan.

Dapatan menunjukkan bahawa pekali regresi pengaruh individu adalah paling tinggi iaitu .138 (CI = .213 hingga .230). Ini menunjukkan bahawa pekali regresi di populasi dari sampel diperolehi adalah positif, $\mathrm{t}=$ 2.718: $p<.05$. Manakala Nilai Beta menunjukkan bahawa bahawa pekali korelasi bagi dimensi pengaruh individu adalah yang paling tinggi (pengaruh ideal menunjukkan paling rendah).

Persamaan yang meramalkan Pembangunan Kerjaya (PK) adalah seperti berikut:

$$
\begin{aligned}
& \mathrm{Y} 2=\text { Konstan }+\mathrm{X} 1+\mathrm{X} 2+\mathrm{X} 3=\mathrm{X} 4 \\
& \mathrm{PK}=1.717+.0 .85+0.81+0.138+0.104=3.679
\end{aligned}
$$

$\mathrm{H}_{\text {la }} \quad$ Terdapat hubungan signifikan antara pengaruh ideal terhadap pembangunan kerjaya.

Berdasarkan kepada analisa regresi pelbagai antara ciri pengaruh ideal dengan penyediaan program pembangunan kerjaya, dapatan kajian menunjukkan bahawa pengaruh ideal mempunyai hubungan yang tidak signifikan dengan program pembangunan kerjaya iaitu nilai signifikannya ialah .193. Pekali beta bagi perhubungan ini ialah .081 dan nilai $\mathrm{t}$ ialah 1.304. Hipotesis bagi $\mathrm{H}_{1 \mathrm{a}}$ adalah ditolak.

$\mathrm{H}_{\mathrm{lb}}$ Terdapat hubungan signifikan antara motivasi berinspirasi terhadap pembangunan kerjaya.

Hasil dapatan kajian menunjukkan bahawa motivasi inspirasi mempunyai hubungan yang yang tidak signifikan dengan program pembangunan kerjaya iaitu nilai signifikannya ialah .160. Pekali beta bagi perhubungan ini ialah .093 dan nilai t ialah 1.409. Hipotesis bagi $\mathrm{H}_{1 \mathrm{~b}}$ adalah ditolak.

$\mathrm{H}_{1 \mathrm{c}}$ Terdapat hubungan signifikan antara pengaruh individu terhadap pembangunan kerjaya.

Hasil analisis regresi pelbagai responden mengenai ciri pengaruh individu kepemimpinan terhadap program pembangunan kerjaya, dapatan kajian menunjukkan pembolehubah tersebut mempunyai hubungan signifikan dengan nilai signifikan .007 . Nilai pekali beta ialah .165 dengan nilai t ialah 2.718. Sehubungan itu, $\mathrm{H}_{1 \mathrm{c}}$ adalah di terima.

$\mathrm{H}_{1 \mathrm{~d}}$ Terdapat hubungan signifikan antara pengaruh rangangan intelektual pembangunan kerjaya.

Dapatan kajian menunjukkan bahawa rangsangan intelek mempunyai hubungan yang tidak signifikan dengan program pembangunan kerjaya iaitu nilai signifikannya ialah .013. Pekali beta bagi perhubungan ini ialah .105 dan nilai t ialah 1.633. Hipotesis bagi $\mathrm{H}_{1 \mathrm{~d}}$ adalah ditolak.

Dapatan kajian menunjukkan bahawa ciri pemimpin pengaruh individu merupakan pembolehubah yang dominan mempengaruhi program pelan penggantian berdasarkan kepada persepsi responden. Jadual 3 menunjukkan bahawa pengaruh individu adalah berkait rapat secara positif dan signifikan, manakala pembolehubah bebas lain iaitu ciri pengaruh ideal, motivasi dan rangsangan intelek tidak mempunyai hubungan signifikan dengan program kerjaya. Pekali regrasi pengaruh individu yang paling tinggi .165. Hal ini menunjukkan bahawa pekali regresi di populasi dari mana sampel diperolehi adalah positif, $t=2.718$ : $p$ $<0.05$. Nilai Beta menunjukkan bahawa pekali korelasi bagi pengaruh individu mempunyai kesan yang positif dan signifikan serta dominan terhadap pembolehubah bersandar pembangunan kerjaya.

Hasil dapatan seperti yang ditunjukkan dalam Jadual 3, model regresi yang didapati ialah $(\mathrm{F}=7.871$ : $\mathrm{Sig} .=.000)$. $\mathrm{R}^{2}$ menunjukkan pekali penentuan pembolehubah bebas kepada pembolehubah bersandar. Berdasarkan kepada Jadual $1, \mathrm{R}^{2}$ menunjukkan nilai .141 yang bermaksud $14.1 \%$ yang menunjukkan hubungan signifikan dan kolektif oleh pembolehubah bebas terhadap pembolehubah bersandar. Menurut Hair et al. (2010), untuk menentukan pembolehubah yang mempunyai pengaruh yang paling tinggi dengan melihat nilai Beta. Kajian menunjukkan bahawa pengaruh individu membuktikan nilai terbesar Beta.165 pada aras .007. Ini bermakna berdasarkan kepada persepsi responden pengaruh individu pemimpin memainkan peranan penting dalam proses pembangunan kerjaya.

\section{PERBINCANGAN}

Pemuan penting kajian ini ialah perancangan penggantian dipengaruhi oleh ciri kepimpinan dari persepsi orang bawahan terhadap kempat-empat dimensi gaya kepemimpinan. Dapatan kajian menunjukkan bahawa dimensi yang paling dominan mempengaruhi perlaksanaan program pembangunan kerjaya berdasarkan kepada persepsi responden ialah pengaruh individu.Tetapi yang lebih penting lagi, penemuan kajian ini memberikan beberapa pandangan praktikal mengenai keperluan sektor awam untuk melihat semula perancangan penggantian dan gaya kepemimpinan kerana ini mempunyai kelebihan penting pada persepsi orang bawahan. Ini adalah pandangan timbal balik antara pemimpin dan orang bawahan yang membawa kepada isyarat yang dibentuk dari persekitaran tempat kerja. Para pemimpin perlu memahami bahawa prasangka dan penilaian prestasi subjektif dapat menimbulkan tanggapan yang negatif daripada orang bawahan.

Justeru, penilaian orang bawahan secara objektif dan jujur memudahkan para pemimpin mentadbir organisasi. Ianya konsisten dengan Spendlove (2007) dan Soene, Butler dan Stanton (2015) yang menunjukkan bahawa campur tangan kepemimpinan perlu bermula jauh lebih awal dalam laluan kerjaya, supaya kejayaan dibina dari bawah, dan bukannya dari atas. Penemuan penting ini adalah sejajar dengan penyelidik terdahulu yang meneliti hubungan antara kepimpinan transformasional dan kesejahteraan (Skakon et al. 2010). Hasil dapatan ini juga dilihat selari dengan Soene et al. (2015), Floyd 
(2010) dan Notgrass (2014). Malahan penemuan kajian ini juga mengesahkan kepemimpinan memain peranan yang penting dan selari dengan kajian Yusniati et al. (2018) dan Hasel dan Grover (2017). Menurut Bass (1990), pemimpin yang menunjukkan wawasan yang jelas serta memudahkan urusan akan meningkatkan persepsi orang bawahan terhadap kejayaan organisasi. Hasil penemuan ini juga adalah konsisten dengan pengkaji-pengkaji yang lain (Voon et al. 2011; Hinduan et al. 2009; Chi et al. 2017).

Secara teorinya, kajian ini telah berjaya menyumbang kepada literatur berkaitan mengenai perancangan penggantian. Penemuan menunjukan bahawa kejayaan pembangunan kerjaya harus diterajui oleh kepemimpinan transformasional yang berkarisma. Walau bagaimanapun, tindakan subordinat harus dipacu secara berkesan oleh sokongan yang kuat yang diberikan oleh pemimpin transformasi. Penjelasan ini dapat disimpulkan bahawa subordinat benar-benar bergantung kepada pemimpin untuk menyediakan panduan yang jelas, mengenai cara meningkatkan peluang kerjaya. Oleh itu, penemuan kajian ini adalah penting kerana ia boleh digunakan oleh Jabatan Perkhidmatan Awam Malaysia dalam melaksanakan program perancangan penggantian dan menggalakkan keberkesanan organisasi. Di samping itu, mengenai hakikat bahawa gaya kepimpinan mempengaruhi proses jalur kerjaya bawahan, organisasi boleh menganggapnya sessuatu yang benilai untuk melabur dalam latihan kepimpinan.

Berdasarkan kepada dapatan kajian terdapat beberapa cadangan yang perlu diberi perhatian. Pertama, pemimpin perlu berkongsi wawasan dan matlamat yang sama antara pemimpin dan subordinat. Visi dan misi organisasi perlu jelas kepada setiap pekerja serta menjadi tonggak utama organisasi. Pekerja juga perlu dirangsang untuk mencapai matlamat dan pemimpin perlu memupuk pemikiran inovatif kepada subordinat untuk meningkatkan produktiviti. Kedua, pemimpin perlu mempunyai kesedaran terhadap laluan kepemimpinan (Pathways to leadership). Pelan penggantian kerjaya untuk melahirkan barisan pemimpin masa hadapan yang berkaliber tidak boleh dijalankan secara "one-off" tetapi merupakan program pelan penggantian jangka panjang untuk memenuhi kepelbagaian kepentingan. Ketiga, persekitaran organisasi yang kondusif juga memainkan peranan yang penting. Bolman dan Deal (1997) menyatakan bahawa kelemahan organisasi adalah juga berpunca "focus too much on the actors and too little on stage they plays their role." Ke empat ialah penurunan kuasa (Empowerment). Majoriti responden melalui kajian menyatakan bahawa keputusan perlaksanaan pelan penggantian adalah bergantung kepada Jabatan Perkhidmatan Awam. Justeru itu pemimpin tertinggi organisasi perlu diberi kuasa autonomi untuk bertindak dan membuat keputusan seperti mana kejayaan perlaksanaan pelan penggantian di Government Link Company (GLC). Perancangan pelan penggantian tidak akan bermakna seandainya iklim organisasi dan pengurusan tertinggi fleksibel menghalang inisiatif dan mengongkong kreativiti pekerja.

\section{KESIMPULAN}

Oleh itu, dapat disimpulkan bahawa kepemimpinan yang berjaya dapat meningkatkan kekuatan mental dan intelektual dalam suatu organisasi kerana berkait rapat dengan budaya sektor awam. Ini kerana kedua-dua pihak pengurusan dan orang bawahan memerlukan sokongan antara satu sama lain. Penyelidikan Gould (1979) membuktikan bahawa kesedaran individu terhadap diri dan alam sekitar, dan tindakan untuk menetapkan matlamat kerjaya akan mempengaruhi motivasi individu mengenai perancangan kerjaya, dan strategi penglibatan akan memudahkan individu menuju jalan kejayaan. Dengan kata lain, perancangan kerjaya dikaitkan dengan strategi kerjaya dan kejayaan kerjaya. Hujah yang popular adalah untuk para pemimpin untuk memimpin dan bukannya mengurus organisasi mereka. Usaha untuk memanfaatkan keupayaan intelektual tenaga kerja memerlukan pemimpin menyampaikan secara objektif, visi dan reka bentuk yang pasti untuk jangka panjang.

\section{RUJUKAN}

Abdullah, H. \& Ainon, M. 2007. Teori dan Teknik Kepimpinan: Panduan Aplikasi di Tempat Kerja. Kuala Lumpur: PTS Professional Publishing Sdn Bhd.

Abdulla, J., Ramdane, D. \& Kamel, M. 2011. Determinations of job satisfaction in the UEA. Personnel Review 40(1): 126-146.

Abouraia, M.K. \& Othman, S.M. 2017. Transformational leadership, job satisfaction, organizational commitment and turnover intentions: The direct effects among Bank representatives. American Journal of Industrial and Business Management 7: 404-423.

Adewale, O.O., Abolaji, A.J. \& Kolade, O.J. 2011. Succession planning organizational survival: Empirical study in Nigeria private tertiary institution. Serbian Journal of Management 6(2): 231-246

Al-Ansi, A.M., Rahardjo, K. \& Prasetya, A. 2015. Analysis impact of leadership style and pay fairness on job satisfaction and organizational commitment. IOSR Journal of Business and Management 17(3): 76-82.

Asrar-ul-Haq, M. \& Kuchinke, K.P. 2016. Impact of leadership styles on employees' attitude towards their leader and performance: Empirical evidence from Pakistani banks. Future Business Journal 2: 54-64.

Barton, A. 2019. Preparing for leadership turnover in Christian Higher Education: Best practices in succession planning. Christian Higher Education 18(1-2): 37-53.

Bass, B.M. 1985. Leadership and Performance Beyond Expectation. New York: Free Press.

Bass, B.M. 1990. Bass \& Stodgill's Handbook of Leadership: Theory, Research and Managerial Implications. 3rd Edition. New York: Free press

Bass, B.M. \& Avolio, B.J. 1999. Training Full Range Leadership: A Resources Guide for Training with the MLQ. Redwood City, CA: Mind Garden.

Bass, B.M. \& Avolio, B.J. 2004. Multifactor Leadership Questionnaire: Manual and Similar Set. 3rd Edition. Redwood City, CA: Mind Garden, Inc.

Bass, B.M. \& Riggio, R.E. 2006. Transformational Leadership. 2nd edition. Mehwah, NJ.: Lawrence Erlbaum Associate 
Bennis, W. \& Nanus, B. 1985. Leader: The Strategies for Taking Charge. New York: Harper \& Row.

Bolman, L.G. \& Deal, T.E. 1997. Reframing Organizations. 2nd edition. San Francisco: Jossey-Basss Publications.

Bowers, B. 2008. Employee development programs help companies achieve greater success. CMA Management 82(2): 13-14

Breaugh, J., Ritz, A. \& Alfes, K. 2017. Work motivation and public service motivation: Disentangling varietis of motivation and job satisfaction. Public Managemen Review 20(10): 171-1940.

Burns, J.M. 1978. Leadership. New York. NY: Harper and Row Publishers.

Chaughtai, A. 2018. Authentic leadership, career self-efficacy career success. A cross-sectional study. Career Development International 23(6): 595-607.

Cerni, T., Curtis, G.J. \& Colmar, S.H. 2014 .Cognitiveexperiential leadership model: How leaders' informationprocessing systems can influence leadership styles, influencing tactics, conflict management, and organizational outcomes. Journal of Leadership Studies 8(3): 26-39.

Chi, H.K., Tsai, H.P. \& Chang, P.F. 2017. Investigating the relationship among leadership styles, emotional intelligence and organization commitment on job performance: A study of salespeople in Thailand. The Journal of Human Resource and Adult Learning 3(2): 199- 212.

Church, A.H., Rotolo, C.T., Ginther, N.M. \& Levine, R. 2015. How are top companies designing and managing theirpotential programs? Consulting Psychology Journal 67(1): 17-47.

Chong, M.P.M. 2014. Influence behaviors and organizational commitment: A comparative study. Leadership and Organization Development Journal 35(1): 54-78.

Earls, A. \& Hall, H.M. 2018. Lesson for succession planning in rural Canada: A review of farm sucession plans and available resources in Haldimand Country, Ontario. Journal of Rural and Community Development 13(4): 25-42.

Falkiner, O., Steena, A., Hicks, J. \& Keogh, D. 2017. Current practises in Australian farm succession planning: Surveying the issues. Financial Planning Research Journal 3(1): 59-74.

Fatimah, O. 2013. Succession planning effective: A case study of UKM. Unpublished Master Diss., Universiti Utara Malaysia.

Floyd, K.S. 2010. Leadership styles, ethics institutionalization, ethical work climate and employee attitudes toward information technology misuse in higher education: A correlational study. Unpublished PhD. Diss., Georgia Sourthern University.

Geh, E.Z. 2014. Organizational spiritual leadership of worlds 'made' and 'found': An experiential learning model for 'feel'. Leadership \& Organization Development Journal 35(2): 137-151

Gennaro, D.D. 2018. Transformational leadership for public service motivation. Journal of Economic and Administrative Sciences 35(1): 5-15.

Gould, S. 1979. Characteristics of career planners in upwardly mobile occupations. Academy of Management Journal 22(3): 539-550.

Guay, R.P. 2013. The relationship between leader fit and transformational leadership. Journal of Managerial Psychology 28(1): 55-73.
Gulzar, S.S. \& Durrani, A.D. 2014. Impact of succession planning on employee engagement in telecommunication sector in Rawalpindi, Pakistan. European Journal of Business and Management 6(37): 274-281.

Hair, J.F., Black, W.C., Babin, B.J. \& Anderson, R.E. 2010. Multivariate Data Analysis. 7th edition. Prentice Hall.

Haider, M.H. \& Riaz, A. 2010. Role of Transformational and transactional leadership on job satisfaction and career satisfaction. Business and Economic Horizon Journal I (1): 29-38.

Hall, J., Johnson, S., Wysocki, A. \& Kepner. K. 2008. Tranformational leadership: The transformation of managers and associates. Available at https://edis.ifas.ufl. edu/pdffiles/ HR/HRD2000 pdf.

Hasel, M.C. \& Grover, S.L. 2017. An integrative model of trust and leadership. Leadership and Organization Development Journal 38(6): 849-867.

Hennessey, J.T. 1998. Reinventing government: Does leadership make the different? Public Administration Review 56(6): 522-532.

Hinduan, Z.R., Evered, E.W., Moss, S. \& Scannell, E. 2009. Leadership, work outcomes and openness to change following on Indonesian bank merger. Asia Pacific Journal of Human Resources 47(1): 59-78.

Ho, L.A. 2011. Mediating, learning orgaizational innovation and performance. Industrial Management and Data System 11(1): 113-131.

Ibarra, P. 2005. Succession planning: An idea whose time has come. Public Management Journal 87(1): 18-24.

Ismail, J., Awis, M.L. \& Mohd Amin, S.H. 2011. Employee attitudes vs employee affective commitment. Global Journal of Human Social Science 11(7): 77-79.

Ismail, A., Ishak, Y. \& Yusuf, M.H. 2016. Human-oriented leadership and organizational commitment in US subsidiary company based in Sarawak. Binus Business Review 7(3): 233-239.

Julia, J. 2009. The relationship between succession planning and career development: Unpublished Master Diss. University Utara Malaysia.

Kirk, J.J., Downey, B., Duckett, S. \& Woody, C. 2000. Name your career development intervention. Journal of Workplace Learning 12(5): 201-216.

Krishnanathan, P. \& Mangaleswaran, T. 2018. Organizational commitment and employee performance with special reference to administrative officers at the University of Jaffna, Sri Lanka. Research Journal of Education 4(6): 82-86.

Leanard, K. 2018. Advantages \& disadvantages of peopleoriented leadership styles. Available at https://smallbusiness. chron.com/advantages-disadvantages-peopleorientedleadershipstyles-10299.html

Lythreatis, S., Sayed, M.A.M. \& Wang, X. 2017. Participative leadership and organizational identification in SMEs in the MENA Region: Testing the roles of CSR perceptions and pride in membership. Journal of Business Ethics: 1-16.

Marshall, J. 2005. Succession Planning is key to smooth process. Financial Executive 21(8): 26-28.

Maurer, T.J., Hartnell, C.A. \& Lippstreau, M. 2017. A model of leadership, motivation, error management culture, leadership capacity and career success. Journal of Occupational and Organizational Psychology 90: 481-507.

McKnight, L.L. 2013. Transformational Leadership in the context of punctuated change. Journal of Leadership, Accountability and Ethics 10(2): 103-112. 
Mehrabani, E.S. \& Mohamad, N.A. 2011. Identifiying the important Factors Influencing the Implementation of Succession Planning. 2011 International Conference on Information and Finance. 37-41, IACSIT Press, Singapore.

Mello, J.A. 2011. Strategic Management of Human Resources. $3^{\text {rd }}$ edition. Canada: South-Western, Cengage Learning.

Megheiurkouni, M. 2018. Self-leadership strategies and career success: Insight on sports organizations. Sports, Business and Management: An International Journal 8(4): 393409.

Mesu, J., Sender, K. \& Riemsdijk, M.V. 2015. Transformational leadership and organisational commitment in manufacturing and service small to medium-sized enterprises: The moderating effects of directive and participative leadership. Personnel Review 44(6): 970-990.

Nabi, N., Islam M., Dip, T.M. \& Hossain, A.A. 2017. Impact of motivation on employee performances: A case study of Karmasangsthan Bank Limited, Bangladesh. Arabian J Bus Manag Review 7: 1-8.

Notgrass, D. 2014. The relationship between followers' perceived quality of relationship style. Leadership Development Journal 35(7): 605-621.

Oh, J., Cho, D. \& Lim, D.H. 2018. Authentic leadership and work engagement: The mediating effect of practicing core values. Leadership and Organization Development Journal 39(2): 276-290

Papa, M.J., Daniel, B.J. \& Spiker, B. K. 1997. Perspective on Organizational Communication: $4^{\text {th }}$ edition. Boston: McGraw Hill.

Rasool, H.F. Arfeen, I.U., Mothi, W. \& Aslam, U. 2015. Leadership styles and its impact on employees' performance in health sector of Pakistan. City University Research Journal 5(1): 97-109.

Rothwell, W. 2005. Putting Succession Planning: Ensuring Leadership Continuity and Building Talent from Within. 3rd edition. New York: Amacom.

Rothwell, W. 2010. Effective Succession Planning, Ensuring Leadership Continuity and Building Talent from Within. 4th edition. New York: American Management Association.

Setyaningrum, R.P., Setiawan, M. \& Surachman. 2017. Organizational commitments are ediation of relationships between servant leadership and employee performance. Journal of Applied Management 15(4): 693-701.

Semarco, S.K.M. \& Cho, S. 2017. The predictive influence of head teachers' task-oriented managerial leadership behaviours on teachers' retention intentions in Ghana Educational Management Administration and Leadership 46(3): 1-18.

Skakon, J., Nielson. K., Borg, V. \& Guzman J. 2010. Is leader well-being, behaviour and style associated with effective of the well-being of their employee? A systematic review of three decades of research. An international Journal of Work, Health \& Organzation 24(2): 107-139.

Soene, E., Butler, C. \& Stanton, E. 2015. Followers' transformational leadership and performance. Sport, Business and Management: An international Journal 5(1): 65-78.
Sosik, J.J. \& Jung, D.I. 2010. Full Range Leadership Development: Pathways for People, Profits, and Planet. Routledge: New York.

Spendlove, M. 2007. Competencies for effective leadership in higher education. International Journal of Educational Management 21(5): 407-417.

Tahir, A.H., Tanveer, A., Faheem, F., Rahman, A. \& Saeed, Z. 2017. Influence of instrumental and participative leadership style on job performance. International Journal of Scientific Footprints 5(2): 1-8.

Ubben, G.C. Hughes, L. \& Norris, C.J. 2004. The Principal: Creative Leadership for Excellence in Schools. Pearson Education, Inc.

Xu, Q., Zhao, Y., Xi, M. \& Zhao, S. 2018. Impact of benevolent leadership on follower taking charge: Roles of work engagement and role-breadth self-efficacy. Chinese Management Studies 12(4): 741-755.

Voon, M.L., Lo, M.C., Ngui, K.S \& Ayob, N.B. 2011. The influence of leadership style on employees's job satisfaction in public sector organization in Malaysia. International Journal of Business Management and Social Science 2(1): 24-32.

Weare, W.H. 2015. Succession planning in academic libraries: A reconsideration. Advances in Library Administration and Organization 34: 313-361.

Wu, Y.C. 2017. Mechanisms linking ethical leadership to ethical sales behavior. Psychological Reports 120(3): 537-560.

Yusniati, I., Ismail, A., Asyakireen, A., Umi Hamidaton, M.S.L. \& Ali, M.H. 2018. Human-oriented leadership and encouragement to perform work: Modelling organizational attachment as mediator. Journal Pengurusan 54: 1-18.

Zepeda, S.J., Bengtson, E. \& Parylo, O. 2011. Examining the planning and management of principal sucession. Journal of Educational Administration 50(2): 136-158.

Zhu, W., Avolio B.J. \& Walumbawa, F.O. 2009. Moderating role of follower characteristics with transformational leadership and follower work engagement. Group and Organization Management 34(5): 590-619.

Zhao, H.H., Seibert, S.E., Taylor, M.S., Lee, C. \& Lam, W. 2016. Not even the past: The joint influence of former leader and new leader during leader succession in the midst of organizational change. Journal of Applied Psychology 101(12): $1730-1738$

Rohana Ahmad (penulis koresponden)

Pusat Pengajian Pembangunan Sosial Dan Ekonomi

Universiti Malaysia Terengganu

21030 Kuala Terengganu, Terengganu, MALAYSIA.

E-Mel: rohana.a@umt.edu.my

Ahmad Martadha Mohamed

Pusat Pengajian Kerajaan

Kolej Undang-Undang, Kerajaan dan Pengajian Antarabangsa

Universiti Utara Malaysia

06010 UUM Sintok, Kedah, MALAYSIA.

E-Mel: martadha@uum.edu.my 